\title{
Decline of Exocrine Pancreatic Function in Cystic Fibrosis Patients with Pancreatic Sufficiency ${ }^{1}$
}

\author{
R. T. L. COUPER ${ }^{2}$ M. COREY, D. J. MOORE, ${ }^{2}$ L. J. FISHER, G. G. FORSTNER, AND \\ P. R. DURIE \\ Division of Gastroenterology, Department of Paediatrics and the Research Institute, The Hospital for Sick \\ Children; and the Department of Pediatrics, University of Toronto, Toronto, Ontario, Canada M5G IX8
}

\begin{abstract}
Patients with cystic fibrosis and pancreatic sufficiency were investigated for evidence of progressive pancreatic disease. From a cohort of 630 patients, 20 pancreatic-sufficient patients became pancreatic insufficient after an average duration of 5.6 y (range 0.6-20.6 y) from diagnosis. Among 54 patients documented to be pancreatic sufficient by direct pancreatic stimulation test, 47 remained pancreatic sufficient and seven developed pancreatic insufficiency. The patients who ultimately developed pancreatic insufficiency were younger and had greatly reduced outputs of enzyme, fluid, and electrolytes. Those who remained pancreatic sufficient showed enzyme secretion close to or within the non-cystic fibrosis control range. Twenty of these patients underwent a second pancreatic stimulation test after an average interval of $4 \mathrm{y}$ (range 1.36.2 y). No significant alteration in enzyme, fluid, or electrolyte output was seen in the patients who remained pancreatic sufficient, but there was further reduction in enzyme and fluid output in the patients who developed pancreatic failure. In conclusion, the majority of pancreatic-sufficient patients with pancreatic enzyme secretion within the control range showed no deterioration of function over an extended time period. However, a small number of pancreatic-sufficient patients with reduced enzyme and fluid secretion are at risk of pancreatic failure. (Pediatr Res 32: 179-182, 1992)
\end{abstract}

Abbreviations

CF, cystic fibrosis

In 1950, Gibbs et al. (1) recognized that a small subset of patients with $\mathrm{CF}$ had sufficient pancreatic function to maintain normal digestion without the need for exogenous pancreatic enzyme supplements. We have coined the term "pancreatic sufficient" to describe $\mathrm{CF}$ patients with normal digestion, which serves to distinguish them from those with pancreatic insufficiency who have fat maldigestion due to pancreatic failure. The exact proportion of pancreatic-sufficient and pancreatic-insufficient patients in the CF population has not been precisely defined. Our cross-sectional clinical data suggest that 12 to $15 \%$ of the population are pancreatic sufficient (2). However, recent data

Received August 27, 1991; accepted March 18, 1992.

Correspondence: Dr. P. R. Durie, Division of Gastroenterology, The Hospital for Sick Children, 555 University Avenue, Toronto, Ontario, Canada, M5G 1 X8.

Supported by research fellowship awards from the Canadian Cystic Fibrosis Foundation (R.T.L.C. and D.J.M.) and from Janssen Pharmaceutica (R.T.L.C.) and by research grants from the Canadian Cystic Fibrosis Foundation (P.R.D. G.G.F., and M.C.).

'G.F., and M.C.).
'Presented in preliminary form at the 10 th International CF Congress, Sydney, Australia, March 1988.

${ }^{2}$ Current address: Adelaide Childrens Hospital, North Adelaide, Australia. in $\mathrm{CF}$ neonates diagnosed by newborn screening reveal that $38 \%$ of CF infants are pancreatic sufficient at diagnosis (3), but $21 \%$ of these patients develop pancreatic insufficiency between 3 and 36 mo of age. This observation supports the previous suggestion that some pancreatic-sufficient patients will develop pancreatic insufficiency with advancing age. Also, in nonscreened populations, the variable age of diagnosis and modes of clinical presentation may be attributed to varying onset of signs and symptoms of pancreatic failure.

There are few data concerning longitudinal changes of exocrine pancreatic function in patients with pancreatic sufficiency. Our current cross-sectional data suggest that pancreatic-sufficient patients are capable of secreting adequate amounts of pancreatic enzymes to ensure normal digestion, but it is important to emphasize that this subgroup of CF patients is characterized by a wide range of acinar capability, from mean values similar to control subjects to enzyme secretory rates as low as 1 to $2 \%$ of the mean normal rate (4). The wide variation of exocrine pancreatic function in pancreatic-sufficient patients together with the fact that these particular patients are prone to recurring attacks of acute pancreatitis (5) strongly suggest that ongoing pancreatic damage occurs. To evaluate this possibility, we have assessed pancreatic-sufficient patients for evidence of progressive pancreatic disease and have attempted to characterize those at risk of developing pancreatic failure.

\section{PATIENTS AND METHODS}

Patients. All patients attending the CF Clinic at The Hospital for Sick Children, Toronto undergo comprehensive clinical evaluation at diagnosis. After confirmation of the diagnosis by at least two elevated sweat chloride determinations ( $>60 \mathrm{mmol} /$ L), the patient's pulmonary, nutritional, and pancreatic status is determined. This study includes a cohort of 630 patients who were assessed for pancreatic status by a combination of techniques, which are outlined below. Those with documented pancreatic insufficiency are prescribed pancreatic enzyme supplements with meals. Patients with pancreatic sufficiency, who do not require enzyme supplementation, are carefully monitored for evidence of pancreatic failure. Fifty-four pancreatic-sufficient patients (mean age $13.0 \pm 9.9 \mathrm{y}$; range $0.2-37.9 \mathrm{y} ; 34$ males) were quantitatively evaluated by direct pancreatic function test, and exocrine pancreatic function was evaluated longitudinally using a combination of assessment techniques (described below) to monitor their pancreatic function status. Twenty of these patients (mean age $10.7 \pm 8.8 \mathrm{y}$; range $0.3-29.5 \mathrm{y} ; 14$ males) also underwent sequential assessment by direct pancreatic stimulation test. The mean interval between tests was $4.0 \pm 1.4 \mathrm{y}$; range 1.3-6.2 y. Data previously obtained from 15 normal controls (mean age $14.2 \pm 11.3 \mathrm{y}$, range $1.5-28.0 \mathrm{y} ; 11$ males) are included for comparison.

Assessment of exocrine pancreatic function. The following procedures for evaluating and monitoring pancreatic function 
have been established as a clinical routine for patients attending the CF Clinic. However, some of the pancreatic stimulation tests were performed as part of research studies, which were approved by the institutional review board and with informed consent from each patient and/or guardian.

Pancreatic function was assessed by one or more of three methods. Three- to 5-d pooled stool collections were obtained and stored at $4^{\circ} \mathrm{C}$ and fecal fat content was determined by the method of van de Kamer et al. (6). In patients receiving mediumchain triglycerides, the fecal fat content was analyzed by the method of Jeejeebhoy et al. (7). If the patient had been receiving pancreatic enzymes with meals, enzyme supplements were discontinued at least $48 \mathrm{~h}$ before commencement of the stool collection. Fecal fat excretion, expressed as a percentage of mean daily fat intake, was calculated by weighing food intake and by reference to standard food content tables. Pancreatic sufficiency was defined as a fecal fat excretion of $\leq 7 \%$ in patients older than $6 \mathrm{mo}$ of age or $\leq 15 \%$ in patients under 6 mo of age (8).

Serum cationic trypsinogen was measured by a double antibody RIA procedure as described previously $(9,10)$. Crosssectional analysis of our CF population has shown that levels below the reference range $(16.9-46.5 \mu \mathrm{g} / \mathrm{L})$ are a reliable predictor of pancreatic insufficiency, and this is a consistent observation in pancreatic-insufficient patients with $\mathrm{CF}$ who are older than 7 $y$ of age (11). This evaluation was performed every 6 to $12 \mathrm{mo}$. In the majority of subjects, if this test suggested that a patient had developed pancreatic insufficiency or if clinical symptoms suggested pancreatic failure, a fat balance study and/or pancreatic stimulation test was performed as well.

The direct pancreatic stimulation test was performed according to a previously described and validated duodenal marker perfusion technique while maximally stimulating pancreatic secretions with i.v. secretin and cholecystokinin $(12,13)$. Duodenal aspirates were analyzed for colipase, total lipase, and tryptic activity by titermetric techniques $(4,14)$. Bicarbonate was measured by a colorimetric technique (15), and sodium, potassium, and chloride concentration by flame emission photometry. Patients were considered to be pancreatic sufficient if colipase output exceeded $120 \mathrm{U} / \mathrm{kg}$ body $\mathrm{wt} / \mathrm{h}$ or trypsin output exceeded $50 \mathrm{U} / \mathrm{kg}$ body $\mathrm{wt} / \mathrm{h}(4,13)$.

Data analysis. All results are expressed as the mean \pm 1 SD. Comparisons were made using the unpaired $t$ test assuming equal or unequal variance of data as appropriate. $p$ values below 0.05 were regarded as significant. All data were analyzed using the Statistical Analysis System.

\section{RESULTS}

Progression from pancreatic sufficiency to pancreatic insufficiency. Out of 630 patients assessed for pancreatic status, 20 were pancreatic sufficient at diagnosis but later became pancreatic insufficient. The mean age at diagnosis was $3.5 \pm 4.7$ y (range $0.2-14.1 \mathrm{y}$ ). Pancreatic insufficiency became manifest after an average duration of $5.6 \pm 3.9 \mathrm{y}$ (mean age of $9.1 \pm 5.9 \mathrm{y}$; range $0.6-20.6$ y). Six patients developed pancreatic insufficiency before $5 \mathrm{y}$ of age, eight were between 5 and $10 \mathrm{y}$, and six were older than $10 \mathrm{y}$. In 14 of these patients, progression to pancreatic failure was documented by serial fecal fat determinations (Fig. 1). Two patients who had normal fecal fat determinations when first tested subsequently developed low serum cationic trypsinogen determinations $(14.8$ and $7.9 \mu \mathrm{g} / \mathrm{L})$ at 15.2 and $16 \mathrm{y}$ of age, respectively. In another patient, fecal fat determination confirmed the pancreatic-sufficient status at diagnosis, and a pancreatic stimulation test performed 1.3 y later confirmed progression to pancreatic insufficiency. In the remaining three patients, the presence of pancreatic sufficiency was documented at diagnosis $(0.6-0.75 \mathrm{y})$ by direct pancreatic function test; two showed reduced serum cationic trypsinogen levels $(1.0$ and $12.9 \mu \mathrm{g} / \mathrm{L}$ at 8.25 and $7.0 \mathrm{y}$, respectively), and the third exhibited pancreatic failure on the basis of a second pancreatic stimulation test.

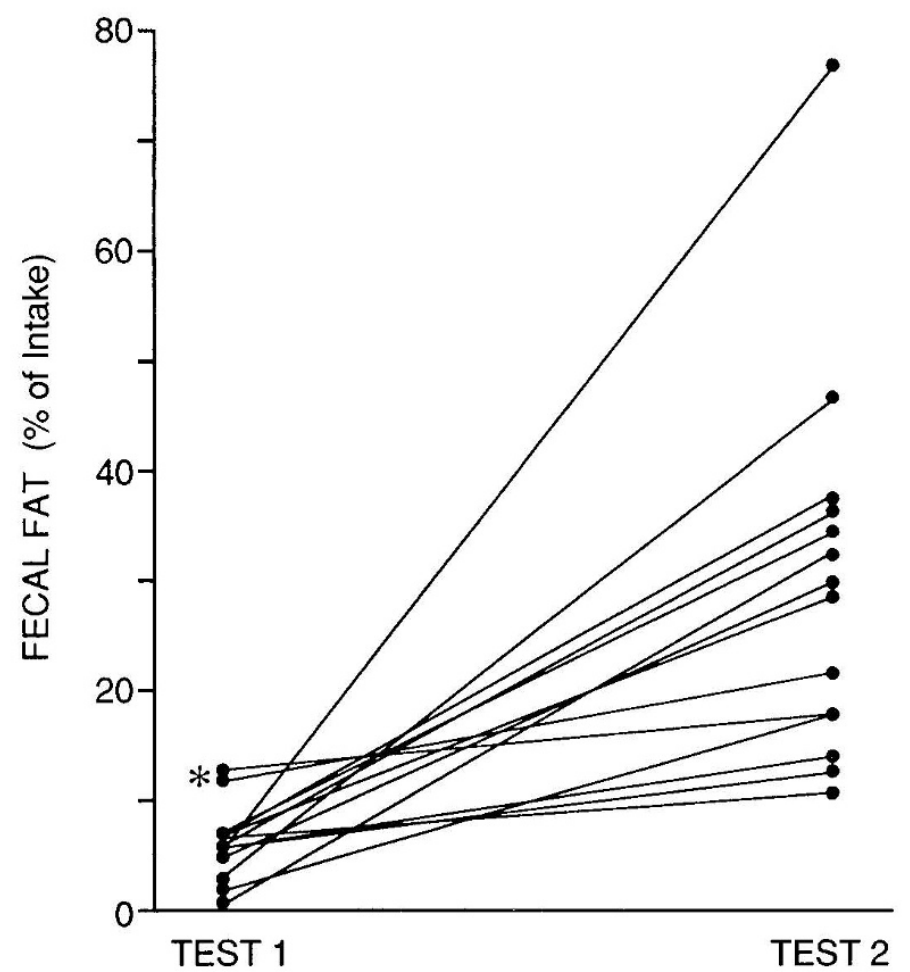

Fig. 1. Fecal fat losses expressed as a percentage of daily fat intake in 14 pancreatic-sufficient patients who later developed pancreatic insufficiency. Test 1 denotes the initial test that confirms pancreatic sufficiency. Test 2 shows the fecal fat data when pancreatic insufficiency occurred. Two patients were less than 6 mo of age when first tested (noted by asterisk).

Direct evaluation of pancreatic function in pancreatic-sufficient subjects. Among the $54 \mathrm{CF}$ subjects documented to be pancreatic-sufficient by direct pancreatic stimulation test, 47 remained pancreatic sufficient. The remaining seven patients developed pancreatic insufficiency. At the initial evaluation, the mean age of the patients who developed pancreatic failure was $3.3 \pm 3.6$ y (range $0.5-9.9 \mathrm{y}$ ), which was significantly younger than the 47 patients who remained pancreatic sufficient (mean age $14.4 \pm 9.8 \mathrm{y}$; range $0.2-37.9 \mathrm{y} ; p<0.0001$ ). Pancreatic insufficiency occurred shortly after an elapsed time of $4.0 \pm 2.8$ y (range 1.1-7.4 y). In contrast, the CF patients who remained pancreatic sufficient retained their pancreatic-sufficient status for a mean duration of $6.4 \pm 3.0$ y (range $0.3-12.7 \mathrm{y}$ ) from diagnosis. Examination of the initial pancreatic stimulation test results (Table 1) shows a wide range of values for all parameters of pancreatic function. The patients who remained pancreatic sufficient had significantly greater pancreatic fluid output and enzyme secretion than those who developed pancreatic insufficiency.

Twenty pancreatic-sufficient patients underwent a second pancreatic stimulation test after an average interval of $4.0 \pm 1.4 \mathrm{y}$ (range 1.3-6.2 y). The outputs of enzyme, fluid, and electrolytes for the first and second stimulation tests are shown in Table 2. Sixteen patients remained pancreatic sufficient over a mean period of $4.4 \pm 2.6 \mathrm{y}$. No significant alteration in enzyme, fluid, or bicarbonate secretion was seen in the patients who remained pancreatic sufficient. Four patients developed pancreatic insufficiency, but in three pancreatic failure occurred shortly after the second test was performed. In those who became pancreatic insufficient, the initial stimulation test showed markedly reduced enzyme and electrolyte output, and, when retested after an average elapsed time of $3.0 \pm 2.2 \mathrm{y}$ (range $1.3-5.5 \mathrm{y}$ ), there was further reduction in trypsin, lipase, and colipase output. The alteration in fluid output was less pronounced, and bicarbonate secretion, which was already low, showed no change. 
Table 1. Direct pancreatic function results (mean $\pm 1 S D$ and range) in 54 CF patients with pancreatic sufficiency and 15 controls*

\begin{tabular}{|c|c|c|c|c|}
\hline & $\begin{array}{l}\text { Controls } \\
(n=15)\end{array}$ & PS $(n=47)$ & $\mathrm{PS} \rightarrow \mathrm{PI}(n=7)$ & $\begin{array}{c}p \text { value } \\
\text { PS } \rightarrow \text { PI } v \text { PS }\end{array}$ \\
\hline Fluid $(\mathrm{mL} / \mathrm{kg} / \mathrm{h})$ & $\begin{array}{l}9.80 \pm 4.0 \\
(7.20-21.26)\end{array}$ & $\begin{array}{l}4.85 \pm 3.35 \\
(0.55-16.2)\end{array}$ & $\begin{array}{l}2.43 \pm 1.16 \\
(1.30-4.81)\end{array}$ & 0.0011 \\
\hline Trypsin $(\mathrm{U} / \mathrm{kg} / \mathrm{h})$ & $\begin{array}{l}2409 \pm 931 \\
(1193-3960)\end{array}$ & $\begin{array}{c}1161 \pm 743 \\
(64-3346)\end{array}$ & $\begin{array}{r}260 \pm 178 \\
(78-578)\end{array}$ & 0.0001 \\
\hline Colipase $(\mathrm{U} / \mathrm{kg} / \mathrm{h})$ & $\begin{array}{c}12259 \pm 5772 \\
(6264-30343)\end{array}$ & $\begin{array}{c}7283 \pm 7325 \\
(144-41716)\end{array}$ & $\begin{array}{l}481 \pm 254 \\
(104-813)\end{array}$ & 0.0001 \\
\hline Total lipase (U/kg/h) & $\begin{array}{c}20532 \pm 9632 \\
(7734-45922)\end{array}$ & $\begin{array}{c}11063 \pm 8155 \\
(172-34625)\end{array}$ & $\begin{array}{l}705 \pm 211 \\
(443-1012)\end{array}$ & 0.0001 \\
\hline $\mathrm{HCO}_{3}(\mathrm{mmol} / \mathrm{kg} / \mathrm{h})$ & $\begin{array}{l}0.60 \pm 0.23 \\
(0.28-1.07)\end{array}$ & $\begin{array}{l}0.20 \pm 0.18 \\
(0.01-0.67)\end{array}$ & $\begin{array}{l}0.12 \pm 0.24 \\
(0.01-0.66)\end{array}$ & 0.40 \\
\hline $\mathrm{Cl}(\mathrm{mmol} / \mathrm{kg} / \mathrm{h})$ & & $\begin{array}{l}0.33 \pm 0.24 \\
(0.07-1.12)\end{array}$ & $\begin{array}{l}0.24 \pm 0.06 \\
(0.15-0.30)\end{array}$ & 0.03 \\
\hline $\mathrm{Na}(\mathrm{mmol} / \mathrm{kg} / \mathrm{h})$ & & $\begin{array}{l}0.65 \pm 0.43 \\
(0.14-2.03)\end{array}$ & $\begin{array}{c}(0.42 \pm 0.12) \\
(0.25-0.56)\end{array}$ & 0.007 \\
\hline $\mathrm{K}(\mathrm{mmol} / \mathrm{kg} / \mathrm{h})$ & & $\begin{array}{c}0.035 \pm 0.027 \\
(0-0.11)\end{array}$ & $\begin{array}{l}0.035 \pm 0.043 \\
(0.001-0.12)\end{array}$ & 0.96 \\
\hline
\end{tabular}

* Forty-seven patients remained pancreatic sufficient and seven developed pancreatic insufficiency (PS $\rightarrow$ PI). PS, pancreatic sufficient; PI, pancreatic insufficient.

Table 2. Sequential pancreatic stimulation test data (mean $\pm 1 S D$ and range) in 20 CF patients with pancreatic sufficiency*

\begin{tabular}{|c|c|c|c|c|}
\hline & \multicolumn{2}{|c|}{ PS $(n=16)$} & \multicolumn{2}{|c|}{$\mathrm{PS} \rightarrow \mathrm{PI}(n=4)$} \\
\hline & Test 1 & Test 2 & Test 1 & Test 2 \\
\hline Age (y) & $\begin{array}{c}12.6 \pm 8.6 \\
(0.3-29.4)\end{array}$ & $\begin{array}{c}16.9 \pm 8.8 \\
(3.3-32.7)\end{array}$ & $\begin{array}{l}3.1 \pm 4.5 \\
(0.8-9.9)\end{array}$ & $\begin{array}{l}6.1 \pm 6.2 \\
(2.3-15.4)\end{array}$ \\
\hline Fluid $(\mathrm{mL} / \mathrm{kg} / \mathrm{h})$ & $\begin{array}{l}4.5 \pm 2.6 \\
(0.6-10.9)\end{array}$ & $\begin{array}{l}4.1 \pm 2.6 \\
(0.3-9.0)\end{array}$ & $\begin{array}{l}2.6 \pm 1.6 \\
(1.3-4.8)\end{array}$ & $\begin{array}{l}2.0 \pm 0.6 \\
(1.3-2.9)\end{array}$ \\
\hline Trypsin $(\mathrm{U} / \mathrm{kg} / \mathrm{h})$ & $\begin{array}{c}1116 \pm 635 \\
(227-2308)\end{array}$ & $\begin{array}{c}1108 \pm 578 \\
(175-2145)\end{array}$ & $\begin{array}{r}198 \pm 125 \\
(78-340)\end{array}$ & $\begin{array}{l}55 \pm 23 \\
(36-87)\end{array}$ \\
\hline Colipase $(\mathrm{U} / \mathrm{kg} / \mathrm{h})$ & $\begin{array}{l}6244 \pm 3508 \\
(1469-13834)\end{array}$ & $\begin{array}{l}7817 \pm 5818 \\
(1053-22655)\end{array}$ & $\begin{array}{l}422 \pm 284 \\
(104-682)\end{array}$ & $\begin{array}{c}158 \pm 80 \\
(38-207)\end{array}$ \\
\hline Total lipase $(\mathrm{U} / \mathrm{kg} / \mathrm{h})$ & $\begin{array}{c}11226 \pm 6633 \\
(1710-21741)\end{array}$ & $\begin{array}{c}12816 \pm 8496 \\
(1826-29657)\end{array}$ & $\begin{array}{l}612 \pm 203 \\
(443-903)\end{array}$ & $\begin{array}{r}345 \pm 194 \\
(95-567)\end{array}$ \\
\hline Bicarbonate $(\mathrm{mmol} / \mathrm{kg} / \mathrm{h})$ & $\begin{array}{l}0.17 \pm 0.14 \\
(0.02-0.48)\end{array}$ & $\begin{array}{l}0.24 \pm 0.20 \\
(0.01-0.66)\end{array}$ & $\begin{array}{l}0.04 \pm 0.03 \\
(0.02-0.08)\end{array}$ & $\begin{array}{l}0.05 \pm 0.03 \\
(0.03-0.01)\end{array}$ \\
\hline
\end{tabular}

* Sixteen patients remained pancreatic sufficient. Four patients developed pancreatic insufficiency (PS $\rightarrow$ PI). PS, pancreatic sufficient; PI, pancreatic insufficient.

\section{DISCUSSION}

This study documents for the first time that the majority of $\mathrm{CF}$ patients who are pancreatic sufficient at diagnosis maintain sufficient exocrine pancreatic function to facilitate normal nutrient assimilation for long periods of time. These data were obtained by using a combination of previously validated tests to identify pancreatic-sufficient patients and to monitor disease progression. A subset of pancreatic-sufficient patients developed pancreatic insufficiency over a variable period of time. Differences in pancreatic function were identified when the two groups were compared. Pancreatic-sufficient patients who ultimately developed pancreatic insufficiency had greatly reduced fluid, electrolyte, and enzyme secretions when first tested in comparison with those who remained pancreatic sufficient. As expected, serial assessment revealed a further reduction in fluid and enzyme secretion.

Pancreatic disease in CF is due to a primary defect in epithelial electrolyte permeability within the ducts that results in reduced ductular fluid flow, producing hyperconcentrated proteinaceous secretions that precipitate and block pancreatic ductules $(16,17)$. This observation is based on direct evidence of reduced fluid output and increased concentration of secreted proteins in comparison with matched non-CF subjects (18-22). The finding of a greater reduction of fluid output in tandem with reduced enzymatic output in pancreatic-sufficient patients who develop pancreatic failure provides strong evidence for progressive pathology presumably due to ductal obstruction and acinar atrophy. However, the number of pancreatic-sufficient patients who progress to pancreatic insufficiency represents a small minority of a crosssectional $C F$ population. These data contrast with the recent report of Waters et al. (3), who revealed that $38 \%$ of CF patients diagnosed by newborn screening were pancreatic sufficient; approximately $20 \%$ of the patients developed pancreatic failure by $3 \mathrm{y}$ of age. The high proportion of pancreatic-sufficient patients in Waters' study and the large percentage who developed pancreatic failure can be attributed to early diagnosis. In the absence of a newborn screening program, many of these patients would not have been diagnosed until symptoms of maldigestion became manifest. Indeed, most of our pancreatic-sufficient patients who became pancreatic insufficient did so before $10 \mathrm{y}$ of age.

The presence or absence of exocrine pancreatic insufficiency is of prognostic importance. Those with pancreatic sufficiency are diagnosed at a later age, presumably because of milder symptoms, have lower mean sweat chloride levels, maintain better pulmonary function with age, and are less likely to have pulmonary colonization with Pseudomonas infections $(2,23)$. They grow normally in childhood and generally do not lose weight as adults. Survival is far superior to those with pancreatic insufficiency. We have shown that genetic factors influence the degree of pancreatic disease and probably its rate of progression. In support of this, we have observed remarkable concordance of pancreatic function status among affected members within the same family (24). We also noted a striking difference between 
pancreatic-sufficient and pancreatic-insufficient groups with respect to allelic and haplotype distribution of DNA markers tightly linked to the CF locus (25). This finding has now been confirmed after identification and isolation of the CF gene and delineation of the major $\mathrm{CF}$ mutation $\left(\Delta \mathrm{F}_{508}\right)$, a 3-bp deletion resulting in the loss of single phenylalanine residue at amino acid position 508 of the predicted gene product (26-29). These data suggest that the variable clinical expression of disease is in part attributable to specific mutations at the CF locus.

Identification of the various mutations in the CF gene is also important because their characterization may provide insight into the molecular consequences of $\mathrm{CF}$. For example, it is quite likely that mutant alleles giving rise to mild disease expression may occur as a result of derangement of the putative CF protein, which may not impair transmembrane ion transport as severely. The identification of various mutant alleles may lead to the identification of a variety of functional defects and eventually may provide alternative pharmacologic mechanisms whereby the underlying functional defect can be promoted, bypassed, or replaced. Further characterization of the differences in phenotypic expression of pancreatic disease in CF at the cellular and molecular level will help to facilitate such advances.

\section{REFERENCES}

1. Gibbs GE, Bostick WL, Smith PM 1950 Incomplete pancreatic deficiency in cystic fibrosis of the pancreas. Pediatrics 37:380-385

2. Gaskin K, Gurwitz D, Durie P, Corey M, Levison H, Forstner G 1982 Improved respiratory prognosis in patients with cystic fibrosis and normal fat absorption. J Pediatr 100:857-862

3. Waters DL, Dorney SFA, Gaskin KJ, Grauca MA, O'Halloran M, Wilcken B 1990 Pancreatic function in infants identified as cystic fibrosis in a neonatal screening program. N Engl J Med 322:303-308

4. Gaskin KJ, Durie PR, Lee L, Hill R, Forstner GG 1984 Colipase and lipase secretion in childhood-onset pancreatic insufficiency: delineation of patients with steatorrhea secondary to relative colipase deficiency. Gastroenterology $86: 1-7$

5. Shwachman H, Lebenthal E, Khaw K-T 1975 Recurrent acute pancreatitis in patients with cystic fibrosis with normal pancreatic enzymes. Pediatrics 55:86-95

6. van de Kamer HH, Huinick H, Weyers HA 1949 Rapid method for determination of fat in feces. J Biol Chem 177:347-351

7. Jeejeebhoy KN, Ahmed S, Kozak G 1970 Determination of faecal fats containing both medium and long-chain triglycerides and fatty acids. Clin Biochem 3:157-163

8. Fomon SJ, Ziegler ER, Thomas LN, Jensen RL, Filer LJ 1970 Excretion of fat by normal full-term infants fed various milks and formulas. Am $\mathbf{J}$ Clin Nutr 23:1299-1313

9. Geokas MC, Largman C, Brodrick JW, Johnson JH 1979 Determination of human pancreatic cationic trypsinogen in serum by radioimmunoassay. Am J Physiol 236:E77-E83

10. Largman C, Brodrick JW, Johnson JH 1981 Radioimmunoassay determina- tion of circulating pancreatic endopeptidases. Methods Enzymol 74:272290

11. Durie PR, Forstner GG, Gaskin KJ, Moore DJ, Cleghorn GJ, Wong SS, Corey ML 1986 Age related alterations of immunoreactive pancreatic cationic trypsinogen in sera from cystic fibrosis patients with and without pancreatic sufficiency. Pediatr Res 20:209-213

12. Go KLW, Hofmann AF, Summerskill WHJ 1970 Simultaneous measurements of total pancreatic, biliary and gastric outputs in man using a perfusion technique. Gastroenterology 58:321-328

13. Gaskin K, Durie P, Corey M, Wei P, Forstner G 1982 Evidence for a primary defect of pancreatic bicarbonate secretion in cystic fibrosis. Pediatr Res 16:554-557

14. Dyck WP 1967 Titremetric measurements of fecal trypsin and chymotrypsin in cystic fibrosis with pancreatic insufficiency. Am J Dig Dis 12:310-317

15. Skeggs Jr LT 1960 An automatic method for the determination of carbon dioxide in blood plasma. Am J Clin Pathol 33:181-185

16. Kopito L, Shwachman H 1976 The pancreas in cystic fibrosis: chemical composition and comparative morphology. Pediatr Res 24:742-749

17. Imrie JR, Fagan DG, Sturgess JM 1979 Structural and developmental abnormalities of the exocrine pancreas in cystic fibrosis. Am J Pathol 95:697-707

18. Kopelman H, Durie P, Gaskin K, Weizman Z, Forstner G 1985 Pancreatic fluid secretion and protein hyperconcentration in cystic fibrosis. N Engl J Med 312:329-334

19. Kopelman H, Corey M, Gaskin K, Durie P, Weizman Z, Forstner G 1988 Impaired chloride secretion, as well as bicarbonate secretion, underlies the fluid secretory defect in the cystic fibrosis pancreas. Gastroenterology 95:349-355

20. Johansen PG, Anderson CM, Hadorn B 1968 Cystic fibrosis of the pancreas: a generalized disturbance of water and electrolyte movement in exocrine tissue. Lancet 1:455-460

21. Knauff RE, Adams JA 1968 Proteins and mucoproteins in the duodenal fluids of cystic fibrosis and control subjects. Clin Chim Acta 19:245-248

22. Forstner GG, Vesely SM, Durie PR 1989 Selective precipitation of 14 kDa stone/thread proteins by concentration of pancreaticobiliary secretions: relevance to pancreatic ductal obstruction, pancreatic failure and CF. J Pediatr Gastroenterol Nutr 8:313-320

23. Corey M, Gaskin K, Durie P, Levison H, Forstner G 1984 Improved prognosis in CF patients with normal fat absorption. J Pediatr Gastroenterol Nutr 3(suppl 1):S137-S146

24. Corey M, Durie P, Moore D, Forstner G, Levison H 1989 Familial concordance of pancreatic function in cystic fibrosis. J Pediatr 115:274-277

25. Kerem B, Buchanan JA, Durie P, Corey ML, Levison H, Rommens JM, Buchwald M, Tsui L-C 1989 DNA marker haplotype association with pancreatic sufficiency in cystic fibrosis. Am J Hum Genet 44:827-834

26. Rommens JM, Iannuzzi MC, Kerem B-S, Drumm MI, Melmer G, Dean M, Rozmahel R, Cole JL, Kennedy D, Hidaka N, Zsiga M, Buchwald M, Riordan JR, Tsui L-C, Collins FS 1989 Identification of the cystic fibrosis gene: chromosome walking and jumping. Science 245:1059-1065

27. Kerem B, Rommens JM, Buchanan JA, Markiewicz D, Cox TK, Chakravarti A, Buchwald M, Tsui L-C 1989 Identification of the cystic fibrosis gene: genetic analysis. Science 245:1073-1080

28. Riordan JR, Rommens JM, Kerem B-S, Alon N, Rozmahel R, Grzelezak Z Zielenski J, Lok S, Plavsic N, Chou J-L, Drumm MJ, Iannuzzi MC, Collins FS, Tsui L-C 1989 Identification of the cystic fibrosis gene: cloning and characterization of complementary DNA. Science 245:1066-1072

29. Kerem E, Corey M, Kerem B-S, Rommens J, Markiewicz D, Levison H, Tsui L-C, Durie P 1990 The relation between genotype and phenotype in cystic fibrosis: analysis of the most common mutation $\left(\Delta \mathrm{F}_{508}\right)$. N Engl J Med 323:1517-1522 